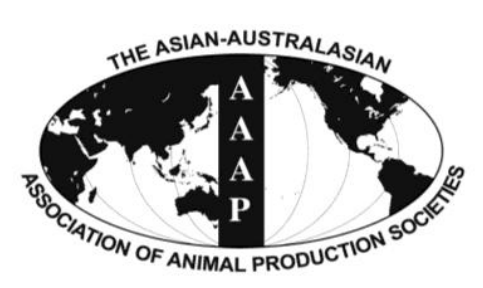

\title{
Effect of y-Aminobutyric Acid-producing Lactobacillus Strain on Laying Performance, Egg Quality and Serum Enzyme Activity in Hy-Line Brown Hens under Heat Stress
}

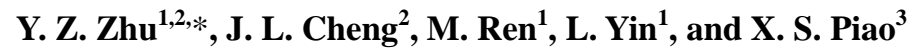 \\ ${ }^{1}$ College of Animal Science, Anhui Science and Technology University, Fengyang 233100, China
}

\begin{abstract}
Heat-stress remains a costly issue for animal production, especially for poultry as they lack sweat glands, and alleviating heat-stress is necessary for ensuring animal production in hot environment. A high $\gamma$-aminobutyric acid (GABA)-producer Lactobacillus strain was used to investigate the effect of dietary GABA-producer on laying performance and egg quality in heat-stressed Hy-line brown hens. Hy-Line brown hens $(n=1,164)$ at 280 days of age were randomly divided into 4 groups based on the amount of freezedried GABA-producer added to the basal diet as follows: i) $0 \mathrm{mg} / \mathrm{kg}$, ii) $25 \mathrm{mg} / \mathrm{kg}$, iii) $50 \mathrm{mg} / \mathrm{kg}$, and iv) $100 \mathrm{mg} / \mathrm{kg}$. All hens were subjected to heat-stress treatment through maintaining the temperature and the relative humidity at $28.83 \pm 3.85^{\circ} \mathrm{C}$ and $37 \%$ to $53.9 \%$, respectively. During the experiment, laying rate, egg weight and feed intake of hens were recorded daily. At the 30th and 60th day after the start of the experiment, biochemical parameters, enzyme activity and immune activity in serum were measured. Egg production, average egg weight, average daily feed intake, feed conversion ratio and percentage of speckled egg, soft shell egg and misshaped egg were significantly improved $(\mathrm{p}<0.05)$ by the increasing supplementation of the dietary GABA-producer. Shape index, eggshell thickness, strength and weight were increased linearly with increasing GABA-producer supplementation. The level of calcium, phosphorus, glucose, total protein and albumin in serum of the hens fed GABA-producing strain supplemented diet was significantly higher $(\mathrm{p}<0.05)$ than that of the hens fed the basal diet, whereas cholesterol level was decreased. Compared with the basal diet, GABAproducer strain supplementation increased serum level of glutathione peroxidase $(p=0.009)$ and superoxide dismutase. In conclusion, GABA-producer played an important role in alleviating heat-stress, the isolated GABA-producer strain might be a potential natural and safe probiotic to use to improve laying performance and egg quality in heat-stressed hens. (Key Words: $\gamma$-Aminobutyric Acid, Lactobacillus, Heat Stress, Laying Performance, Egg Quality)
\end{abstract}

\section{INTRODUCTION}

The negative effect of heat-stress on the welfare of domestic animals is a matter of grave concern (Attia et al., 2009). Heat-stress could reduce feed intake (Rhoads et al., 2009), increase maintenance requirements (Fox and Tylutki, 1998) and decrease diet digestibility (Ole Miaron and Christopherson, 1992). For broilers, heat-stress significantly

\footnotetext{
* Corresponding Author: Y. Z. Zhu. Tel: +86-13615509988, Fax: +86-05506732040, E-mail: zhuyuanzhao111@163.com

${ }^{2}$ Jiangsu Unison Biotechnology Development Co., Ltd., Suqian 233100, China.

${ }^{3}$ Ministry of Agriculture Feed Industry Centre, China Agricultural Univeristy, Beijing 100193, China.

Submitted Feb. 11, 2015; Revised Mar. 27, 2015; Accepted Apr. 25, 2015
}

decreases the activity of intestinal amylase (Feng et al., 2012) and causes a sharp decline of the number of lymphocytes and plasma cells in the jejunum (QuinteiroFilho et al., 2012). In addition, heat-stress also affects growth rate, metabolism, immunity and reproduction of animals with an immeasurable impact (Attia et al., 2011; Bloemhof et al., 2012; Nesamvuni et al., 2012). Although remarkable advances of feeding animals under high-density conditions have been widely applied (Attia et al., 2006; AlHarthi, 2014), heat-stress remains a costly issue for the animal production, especially for poultry as they lack sweat glands. Therefore, alleviating heat-stress is necessary for ensuring animal production in hot environments.

Gamma-aminobutyric acid (GABA), a four-carbon nonprotein amino acid, functions as an inhibitory 
transmitter compound in the central nervous system and some non-neuronal tissues of adult mammals (Watanabe et al., 2002). In recent years, it has been found to be helpful in alleviating heat-stress. The GABA is not only involved in the regulation of a variety of behavioral and physiological response (Sliwowska et al., 2006), but also induces a decrease of body core temperature and an increase of feed intake in chicks in a hot environment (Tajalli et al., 2006; Miyazawa et al., 2012). Furthermore, GABA is beneficial to the performance of chicks through alleviating the negative effects of heat-stress (Dai et al., 2011; Zhang et al., 2012). GABA producing microorganisms (such as lactic acid bacteria $[\mathrm{LAB}]$, fungi and yeast) has attracted attention as a natural and safety strategy for alleviating heat-stress in livestock. Lactic acid bacteria are one of the most commonly used microorganisms in food fermentation, and Lactobacillus species are the main GABA-producing LAB. The GABA producing Lactobacillus brevis $(L b)$. paracasei was firstly isolated from funazushi (Komatsuzaki et al., 2005). Afterward, GABA-producing Lb. buchneri (Cho et al., 2007) and Lb. brevis (Kim et al., 2007) were isolated from kimchi. Li et al. (2008) isolated a high GABAproducer L. brevis NCL912 and developed a fed-batch fermentation process for efficient synthesis of GABA ( $\mathrm{Li}$ et al., 2010). The above studies imply that the microbial production of GABA, especially by LAB strains, has received wide attention. However, few studies have been conducted using a GABA-producing strain to alleviate heatstress in hot summer.

In the present study, we hypothesized that a GABAproducing strain of LAB would have a beneficial effect on heat-stress and in mitigating heat-stress caused damage. Thus, to test this hypothesis, an isolated GABA-produced LAB strain from our laboratory was used to investigate its effect on laying performance, egg quality and immune activity in Hy-Line brown hens under heat-stress.

\section{MATERIALS AND METHODS}

\section{Production of $\gamma$-aminobutyric acid-producing lactic acid bacteria}

The GABA-producing LAB strain was isolated from acidophilus milk by our laboratory. Acidophilus milk was separately inoculated into polypepton yeast extract glucose broth and individual colonies were isolated and purified (Choi et al., 2006). According to the amount of GABA produced, the best isolates for GABA-producing LAB were identified using 16S-rDNA sequence analysis. After $24 \mathrm{~h}$ of incubation at $39^{\circ} \mathrm{C}$, bacterial cells in $0,25,50$, and $100 \mathrm{~mL}$ culture broth of the LAB strain were harvested by centrifuging at 25,000 $\times$ g (Heraeus, Biofuge22R, Hanau, Germany). The harvested cells were suspended and washed well with $10 \mathrm{~mL}$ distilled water, and then re-centrifuged at
$25,000 \times g$, and this procedure was repeated three times. The obtained cells were re-suspended in $10 \mathrm{~mL}$ distilled water and mixed well with $800 \mathrm{mg}$ skimmed milk powder. The mixed materials were first freeze-dried at $-20^{\circ} \mathrm{C}$ for $2 \mathrm{~h}$ and then freeze-dried at $-80^{\circ} \mathrm{C}$ for $14 \mathrm{~h}$ using freeze dryer (HuiChengJia instrument technology Co. Ltd., Beijing, China) to produce $0,25,50$, and $100 \mathrm{~mL} / 800 \mathrm{mg}$ freezedried GABA-producer.

\section{Animals and management}

All animals involved in this study maintained under the guidelines of the Anhui Sciences and Technology University Animal Care and Use Committee (Fengyang, China). A total of 1164 Hy-Line brown hens at 280 days of age were obtained from the animal farm of Anhui Science and Technology University (PR China). All hens were provided with free access to clean water and feed, indoor ventilation and lighting, regular cleaning and disinfection of the corresponding environment. Diets were formulated following the nutrient requirement recommendations of NRC (1994) (Table 1), while the ambient temperature was kept at $28.83 \pm 3.85^{\circ} \mathrm{C}$ (surpassing the optimal ambient temperature range $15^{\circ} \mathrm{C}$ to $23^{\circ} \mathrm{C}$ for laying), and the relative humidity was maintained in the range from $37.2 \%$ to $53.9 \%$ during the entire experiment. Under the above temperature and humidity conditions, the hens would be considered as heat-stressed to a certain extent.

\section{Experiment design}

The 1,164 Hy-Line brown hens were randomly divided

Table 1. Composition and nutrient content of the basal diet (as fed)

\begin{tabular}{lc}
\hline Items & \\
\hline Ingredients (\%) & 63.0 \\
Corn & 20.0 \\
Soybean meal & 3.0 \\
Bran & 9.0 \\
Limestone & 5.0 \\
Premix ${ }^{1}$ & 100.0 \\
Total & \\
Analyzed nutrient content & 10.98 \\
Metabolic energy (MJ/kg) ${ }^{2}$ & 15.30 \\
Crude protein $(\%)$ & 3.49 \\
Calcium (\%) & 0.36 \\
Available phosphorus (\%) & 0.72 \\
Lysine (\%) & 0.34 \\
Methionine (\%) & 0.59 \\
Methionine plus cysteine (\%)
\end{tabular}

${ }^{1}$ Premix, providing Cu $12.5 \mathrm{mg}$, Fe $82.5 \mathrm{mg}$, Se $0.4 \mathrm{mg}$, Zn $87.5 \mathrm{mg}$, I 0.4 mg, Mn $64.0 \mathrm{mg}$, vitamin A 11,000 IU, vitamin D 3,100 IU, vitamin E 18 $\mathrm{mg}$, vitamin K $2.5 \mathrm{mg}$, vitamin $\mathrm{B}_{1} 2.0 \mathrm{mg}$, vitamin $\mathrm{B}_{2} 6.0 \mathrm{mg}$, vitamin $\mathrm{B}_{6}$ $3.6 \mathrm{mg}$, vitamin $\mathrm{B}_{12} 19 \mathrm{mg}$, nicotinic acid $27.0 \mathrm{mg}$, calcium pantothenate $12.0 \mathrm{mg}$, folic acid $0.8 \mathrm{mg}$, and biotin $130 \mathrm{mg} / \mathrm{kg}$ basal diet.

${ }^{2}$ Caculated. 
into 4 groups based on the amount of GABA-producer supplied along with the basal diet with each group consisting of three replicates with 97 hens. The amounts of freeze-dried GABA-producer supplied with the basal diet among the 4 experimental groups were as follows: i) 0 $\mathrm{mg} / \mathrm{kg}$, ii) $25 \mathrm{mg} / \mathrm{kg}$, iii) $50 \mathrm{mg} / \mathrm{kg}$, and iv) $100 \mathrm{mg} / \mathrm{kg}$. A small amount of the basal diets was first mixed with the respective amount of freeze-dried GABA-producer to make a small batch, and the remaining basal diet was added to obtain a homogeneous mixture. The feeding experiment was performed for 60 days after a 15-d adaptation period. The experiment was carried out commencing August 7, 2013 in the animal farm of Anhui Science and Technology University, PR China.

\section{Laying performance measurement}

The laying rate, egg weight, egg mass and feed intake of each group were recorded daily to calculate egg production (laying hens/total hens $\times 100, \%$ ), average egg weight (AEW), feed conversion ratio (total feed intake/total egg mass) and average daily feed intake (ADFI). Meanwhile, the numbers of spot eggs, soft eggs, deformed eggs and sand eggs from each group were also recorded daily to calculate the corresponding index percent (\%). At the 30th and 60th day after the experiment started, three hens were randomly selected from each replicate and were slaughtered. The whole blood was set aside for approximately $20 \mathrm{~min}$ and then centrifuged with $3,000 \times g$ at $4^{\circ} \mathrm{C}$ for $10 \mathrm{~min}$ (Heraeus, Biofuge22R, Germany) and then the serum was stored at $-20^{\circ} \mathrm{C}$ for examining serum biochemical parameters, enzyme activity and immune function.

\section{Egg quality assay}

Thirty-one eggs from each group were collected at the 10th, 20th, 30th, 40th, 50th, and 60th day of the feeding experiment and stored at $4^{\circ} \mathrm{C}$ until analyses (less $1 \mathrm{wk}$ ). Shape index, eggshell thickness, shell strength, shell weight, albumen height, haugh unit, yolk color and weight were determined (Kirunda et al., 2001) using an egg quality determinator (DET6000, NABEL Co., Ltd, Kyoto, Japan).

\section{Serum biochemical parameters}

The levels of calcium, phosphorus, potassium, sodium, glucose, blood urea nitrogen, cholesterol, total protein and albumin (ALB) in hen serum were measured by Nanjing Jian-cheng Bioengineering Institute assay kits (Nanjing, China) following the manufacturer's instructions.

\section{Enzyme activities}

The activities of serum glutathione peroxidase (GSHPx), superoxide dismutase (SOD), malondialdehyde (MDA), lactate dehydrogenase (LDH), creatine phosphokinase (CPK), alkaline phosphatase (ALP) and alanine aminotransferase (ALT) activities were determined by corresponding kits following the manufacturer's instructions. All kits were purchased from Nanjing Jiancheng Bioengineering Institute (Nanjing, China).

\section{Statistical analysis}

Data in the experiment were analyzed using general linear model (GLM) procedure of SAS (2004) according to the following model as equation (1):

$$
Y_{i j k}=\mu+T_{i}+H_{j}+D_{k}+T H D_{i j k}+\varepsilon_{i j k}
$$

where $Y_{i j k}$ is the response variable, $\mu$ is the overall mean, $T_{i}$ is the fixed effect of treatment ( $\mathrm{i}=1$ to 4 ), $H_{j}$ is the random effect of hens $(\mathrm{j}=1$ to 1,164$), D_{k}$ is the random effect of feeding experiment day ( $\mathrm{k}=1$ to 60$), T H D_{i j k}$ is the interaction between treatment $\mathrm{i}$ and day $\mathrm{k}$ in hen $\mathrm{j}$, and $\varepsilon_{i j k}$ is the residual error. Orthogonal polynomial contrasts were performed to determine linear and quadratic effects within freeze-dried GABA-producing LAB bacteria addition treatments. Least square mean and standard error of the means (SEM) were calculated with least square mean statement of the GLM procedure. The replication was used as the unit in analyzing the feeding experimental data. A $p$ value $<0.05$ was considered significant, whereas $0.05 \leq p$ value $<0.10$ was present as tendency.

\section{RESULTS}

Effect of dietary supplement $\gamma$-aminobutyric acidproducing strain on laying performance

As shown in Table 2, increasing dietary supplementation of freeze-dried GABA-producing strain F6 linearly improved egg production $(0.32 \%, 1.76 \%$, and $3.21 \% ; \mathrm{p}<0.001)$, AEW $(0.35 \%, 0.32 \%$, and $1.57 \% ; \mathrm{p}<$ $0.001)$, and ADFI $(1.07 \%, 2.37 \%$, and $2.38 \%$; $<<0.001)$. Compared with the control group, feed conversion ratio and percentage of speckled eggs, soft shell eggs and misshaped eggs from hens fed supplemental freeze-dried GABAproducing strain diet were significantly decreased by $2.35 \%$ $(p<0.001), 8.57 \%(p=0.015), 19.36 \%(p<0.001)$ and 42.46 $(\mathrm{p}<0.001)$, respectively. In addition, calcium coated eggs were quadratically reduced $(\mathrm{p}=0.048)$.

\section{Effect of supplementation of $\gamma$-aminobutyric acid-} producing strain on egg quality

In Table 3 it can be seen that shape index $(1.53 \%$, $1.53 \%$ and $3.07 \% ; \mathrm{p}<0.001)$, eggshell thickness $(3.22 \%$, $3.22 \%$ and $6.45 \% ; \mathrm{p}=0.011)$, eggshell strength $(1.75 \%$, $4.77 \%$ and $5.77 \% ; \mathrm{p}=0.001)$ and eggshell weight $(0.62 \%$, $3.76 \%$ and $6.42 \% ; p=0.025)$ were increased linearly with increasing supplemental dietary freeze-dried GABAproducing strain. Freeze-dried GABA-producing strain 
Table 2. Effect of freeze-dried $\gamma$-aminobutyric acid-producing strain on laying performance in heat-stressed Hy-Line brown hens

\begin{tabular}{|c|c|c|c|c|c|c|c|c|}
\hline \multirow{2}{*}{ Item } & \multicolumn{4}{|c|}{ Dosage of GABA producing Lactobacillus strain $(\mathrm{mg} / \mathrm{kg})$} & \multirow{2}{*}{ SEM } & \multicolumn{3}{|c|}{ p-values } \\
\hline & 0 & 25 & 50 & 100 & & ANOVA & Linear & Quadratic \\
\hline Egg production $(\%)$ & $87.05^{\mathrm{c}}$ & $87.33^{\mathrm{c}}$ & $88.59^{\mathrm{b}}$ & $89.85^{\mathrm{a}}$ & 0.341 & $<0.001$ & $<0.001$ & 0.029 \\
\hline $\mathrm{AEW}(\mathrm{g})$ & $62.07^{\mathrm{b}}$ & $62.29^{\mathrm{b}}$ & $62.27^{\mathrm{b}}$ & $63.05^{\mathrm{a}}$ & 0.083 & $<0.001$ & $<0.001$ & $<0.001$ \\
\hline Egg mass & $54.03^{\mathrm{b}}$ & $54.40^{\mathrm{b}}$ & $55.16^{\mathrm{b}}$ & $56.65^{\mathrm{a}}$ & 0.208 & $<0.001$ & $<0.001$ & $<0.009$ \\
\hline ADFI (g/day) & $109.63^{\mathrm{b}}$ & $110.81^{\mathrm{ab}}$ & $112.23^{\mathrm{a}}$ & $112.24^{\mathrm{a}}$ & 0.692 & 0.027 & 0.004 & 0.407 \\
\hline Feed conversion ratio ${ }^{1}$ & $2.03^{\mathrm{a}}$ & $2.04^{\mathrm{a}}$ & $2.03^{\mathrm{a}}$ & $1.98^{\mathrm{b}}$ & 0.005 & 0.002 & $<0.001$ & 0.008 \\
\hline
\end{tabular}

GABA, $\gamma$-aminobutyric acid; SEM, standard error of the mean; ANOVA, analysis of variance; AEW, average egg weight; ADFI, average daily feed intake.

${ }^{1}$ Feed conversion ratio $=$ ADFI/egg mass.

${ }^{\mathrm{a}, \mathrm{b}, \mathrm{c}}$ Within a row, means that do not have a common superscript letter differ significantly.

supplementation had no significant effect on albumen height, Haugh unit, yolk color, and yolk weight of hens.

Effect of $\gamma$-aminobutyric acid-producing strain supplementation on serum parameters

In hens fed freeze-dried GAGB-producing strain supplemental diets, serum calcium was respectively increased quadratically by $5.93 \%, 10.78 \%$ and $11.65 \%$ (p = 0.040 ), while the concentration of phosphorus showed linear effect $(13.585 \%, 17.93 \%$ and $27.17 \% ; \mathrm{p}=0.026)$, glucose exhibited linear influence $(1.90 \%, 17.12 \%$ and $12.00 \% ; \mathrm{p}=0.029)$, total protein $(1.97 \%, 8.09 \%$ and $5.47 \% ; \mathrm{p}=0.043)$ and ALB $(1.37 \%, 10.07 \%$ and $3.32 \% ; \mathrm{p}$ $=0.012$ ) were linearly improved (Table 4). Furthermore, serum concentration of potassium $(\mathrm{p}=0.070)$ and sodium ( $\mathrm{p}=0.087$ ) tended to increase linearly in hens supplied with freeze-dried GABA-producing strain, whereas serum concentration of cholesterol decreased linearly $(4.77 \%$, $9.55 \%$ and $13.69 \% ; p=0.001)$. No significant difference in blood urea nitrogen was observed among different diet groups $(\mathrm{p}>0.100)$.

Activity of serum enzymes in heat-stressed hens fed

\section{experimental diets}

Table 5 shows the activity of serum enzymes in experimental hens. With increasing supply of dietary freezedried GABA-producing strain, activities of GSH-Px $(2.33 \%$, $25.98 \%$ and $16.12 \% ; \mathrm{p}=0.009)$ and SOD $(4.47 \%, 7.15 \%$ and $6.14 \% ; \mathrm{p}=0.002)$ were linearly increased. While MDA activity $(13.12 \%, 20.58 \%$ and $24.30 \%$; $\mathrm{p}<0.001)$ was reduced and ALP activity tended to increase linearly ( $\mathrm{p}=$ 0.056). The activity of LDH, CPK, and ALT was not significantly affected with increased dietary freeze-dried GABA-producer.

\section{DISCUSSION}

Generally, approximately $2 \%$ of all chicken eggs have some defect, ranging from minor, barely noticeable faults to downright alarming deformities. There are two important factors causing deformity: One is disturbance or stress during calcification process and the other is poor nutrition (for example, low or excess calcium in the hen's diet). In the study, it was noticed that an improvement in the percentage of speckled eggs, soft shell eggs, misshaped eggs and calcium coated eggs in supplemental freeze-dried GABA-

Table 3. Effect of freeze-dried $\gamma$-aminobutyric acid-producing strain on egg quality in heat-stressed Hy-Line brown hens

\begin{tabular}{|c|c|c|c|c|c|c|c|c|}
\hline \multirow{2}{*}{ Item } & \multicolumn{4}{|c|}{ Dosage of GABA producing Lactobacillus strain $(\mathrm{mg} / \mathrm{kg})$} & \multirow{2}{*}{ SEM } & \multicolumn{3}{|c|}{ p-values } \\
\hline & 0 & 25 & 50 & 100 & & ANOVA & Linear & Quadratic \\
\hline Speckled egg (\%) & $19.52^{\mathrm{a}}$ & $19.37^{\mathrm{a}}$ & $17.00^{\mathrm{b}}$ & $17.17^{\mathrm{b}}$ & 0.370 & $<0.001$ & $<0.001$ & 0.676 \\
\hline Soft shell egg $(\%)$ & $2.22^{\mathrm{a}}$ & $1.86^{\mathrm{ab}}$ & $1.74^{\mathrm{b}}$ & $1.77^{\mathrm{b}}$ & 0.132 & 0.030 & 0.015 & 0.145 \\
\hline Misshaped egg (\%) & $0.84^{\mathrm{a}}$ & $0.60^{\mathrm{b}}$ & $0.37^{\mathrm{c}}$ & $0.48^{\mathrm{bc}}$ & 0.075 & $<0.001$ & $<0.001$ & 0.334 \\
\hline Calcium coated egg (\%) & $1.88^{\mathrm{a}}$ & $1.53^{\mathrm{b}}$ & $1.66^{\mathrm{ab}}$ & $1.86^{\mathrm{ab}}$ & 0.131 & 0.206 & 0.919 & 0.048 \\
\hline Shape index & $1.30^{\mathrm{c}}$ & $1.32^{\mathrm{b}}$ & $1.32^{\mathrm{b}}$ & $1.34^{\mathrm{a}}$ & 0.003 & $<0.001$ & $<0.001$ & 0.724 \\
\hline Eggshell thickness (mm) & $0.31^{\mathrm{b}}$ & $0.32^{\mathrm{ab}}$ & $0.32^{\mathrm{ab}}$ & $0.33^{\mathrm{a}}$ & 0.003 & 0.073 & 0.011 & 0.839 \\
\hline Eggshell strength $\left(\mathrm{kgf} / \mathrm{m}^{2}\right)$ & $3.98^{\mathrm{c}}$ & $4.05^{\mathrm{bc}}$ & $4.17^{\mathrm{ab}}$ & $4.21^{\mathrm{a}}$ & 0.046 & 0.013 & 0.001 & 0.690 \\
\hline Eggshell weight (g) & $6.38^{\mathrm{b}}$ & $6.42^{\mathrm{ab}}$ & $6.62^{\mathrm{ab}}$ & $6.79^{\mathrm{a}}$ & 0.124 & 0.130 & 0.025 & 0.617 \\
\hline Albumen height (mm) & 7.07 & 7.10 & 6.92 & 6.95 & 0.233 & 0.933 & 0.608 & 0.708 \\
\hline Haugh unit & 81.02 & 84.12 & 83.82 & 83.32 & 1.478 & 0.467 & 0.337 & 0.246 \\
\hline Yolk color & 8.22 & 8.82 & 8.85 & 8.82 & 0.219 & 0.001 & 0.401 & 0.389 \\
\hline Yolk weight (\%) & 25.21 & 25.82 & 25.93 & 25.69 & 0.249 & 0.147 & 0.478 & 0.440 \\
\hline
\end{tabular}

GABA, $\gamma$-aminobutyric acid; SEM, standard error of the mean; ANOVA, analysis of variance.

${ }^{a, b, c}$ Within a row, means that do not have a common superscript letter differ significantly. 
Table 4. Effect of freeze-dried $\gamma$-aminobutyric acid-producing strain on parameters of serum in heat-stressed Hy-Line brown hens

\begin{tabular}{|c|c|c|c|c|c|c|c|c|}
\hline \multirow{2}{*}{ Item } & \multicolumn{4}{|c|}{ Dosage of GABA producing Lactobacillus strain (mg/kg) } & \multirow{2}{*}{ SEM } & \multicolumn{3}{|c|}{ p-values } \\
\hline & 0 & 25 & 50 & 100 & & ANOVA & Linear & Quadratic \\
\hline$\overline{\text { Calcium (mmol/L) }}$ & $6.40^{\mathrm{b}}$ & $6.78^{\mathrm{ab}}$ & $7.09^{\mathrm{a}}$ & $6.58^{\mathrm{ab}}$ & 0.204 & 0.129 & 0.357 & 0.040 \\
\hline Phosphorus (mmol/L) & $1.84^{\mathrm{b}}$ & $2.09^{\mathrm{ab}}$ & $2.17^{\mathrm{ab}}$ & $2.34^{\mathrm{a}}$ & 0.147 & 0.290 & 0.026 & 0.789 \\
\hline Potassium (mmol/L) & 6.09 & 6.41 & 6.78 & 6.80 & 0.290 & 0.148 & 0.070 & 0.605 \\
\hline Sodium (mmol/L) & 151.5 & 153.0 & 156.0 & 155.8 & 1.99 & 0.326 & 0.087 & 0.680 \\
\hline Glucose (mmol/L) & $8.41^{\mathrm{b}}$ & $8.57^{\mathrm{b}}$ & $9.85^{\mathrm{a}}$ & $9.42^{\mathrm{ab}}$ & 0.409 & 0.065 & 0.029 & 0.481 \\
\hline Cholesterol (mmol/L) & $3.14^{\mathrm{a}}$ & $2.99^{\mathrm{ab}}$ & $2.84^{\mathrm{bc}}$ & $2.71^{\mathrm{c}}$ & 0.089 & 0.015 & 0.001 & 0.904 \\
\hline Total protein $(\mathrm{mg} / \mathrm{mL})$ & $50.75^{\mathrm{b}}$ & $51.75^{\mathrm{ab}}$ & $54.86^{\mathrm{a}}$ & $53.53^{\mathrm{ab}}$ & 1.186 & 0.099 & 0.043 & 0.337 \\
\hline Albumin $(\mathrm{g} / \mathrm{L})$ & $18.95^{\mathrm{b}}$ & $19.21^{\mathrm{b}}$ & $20.86^{\mathrm{a}}$ & $19.58^{\mathrm{ab}}$ & 0.499 & 0.061 & 0.012 & 0.136 \\
\hline Blood urea nitrogen $(\mathrm{mmol} / \mathrm{L})$ & 2.66 & 2.16 & 2.83 & 2.50 & 0.392 & 0.669 & 0.925 & 0.231 \\
\hline
\end{tabular}

GABA, $\gamma$-aminobutyric acid; SEM, standard error of the mean; ANOVA, analysis of variance.

${ }^{a, b, c}$ Within a row, means that do not have a common superscript letter differ significantly.

producing strain diet-fed hens and this may due to the improvement of the GABA-producer. Zhang et al. (2012) demonstrated that GABA not only alleviated stress in hens but also played a great role in regulating appetite and improving nutrition utilization efficiency. The resulting higher concentrations of serum calcium and phosphorus that were observed suggested that a GABA-producer could regulate the utilization of dietary calcium and phosphorus thereby alleviating defected egg caused heat-stress. Mashaly et al. (2004) and Al-Harthi (2014) noted that high ambient temperature has a detrimental effect on laying performance, feed intake and feed conversion efficiency. Therefore, such high ambient temperature might cause a decline in activity of digestive enzymes (e.g. amylase, lipase, and trypsin) in the alimentary canal (Belay and Teeter, 1993; Larbier et al., 1993; Attia et al., 2011). However, GABA has been reported to alleviate heat stress through improving the digestive enzyme activities. Zhang et al. (2012) demonstrated that dietary GABA in Roman hens could increase amylase, lipase and trypsin activities in the gastrointestinal tract, thereby increasing egg production, AEW and ADFI. They observed an increased egg production, AEW and ADFI and improved feed conversion ratio with increasing freeze-dried GABA-producing stain of dietary GABA content. In contrast, the present results indicated that GABA-producing strain of LAB might improve laying performance by alleviating heat-stress.

The basic composition of egg includes protein and yolk. Zhang et al. (2012) noted a significant increase in albumen height, haugh unit, yolk color, and yolk weight in Roman hens at $50 \mathrm{mg} / \mathrm{kg}$ of dietary GABA content. In contrast, the present study demonstrated that GABA-producer had no significantly effect on albumen height, haugh unit, yolk color, and yolk weight. However, the improvement in egg quality in terms of shape index, shell thickness, strength, and weight with increasing dietary GABA-producer content was observed in the present study. Puthpongsiriporn et al. (2001) reported that depressed eggshell thickness and shell strength results in a poorer egg shell quality and shelf-life. Being important components of eggshells, calcium and phosphorus play a crucial role in eggshell weight, shell thickness and shell strength. We also found an increase of absorption and utilization of the dietary mineral substances, especially calcium and phosphorus and this might be the reason for eggshell improvement. The present results are consistent with the report by Zhang et al. (2012), who reported that GABA could modulate the electrolyte balance.

Calcium, phosphorus, potassium, and sodium are not

Table 5. Effect of freeze-dried $\gamma$-aminobutyric acid-producing strain on enzyme activity of serum in heat-stressed Hy-Line brown hens

\begin{tabular}{|c|c|c|c|c|c|c|c|c|}
\hline \multirow{2}{*}{ Item } & \multicolumn{4}{|c|}{ Dosage of GABA producing Lactobacillus strain $(\mathrm{mg} / \mathrm{kg})$} & \multirow{2}{*}{ SEM } & \multicolumn{3}{|c|}{$\mathrm{p}$-values } \\
\hline & 0 & 25 & 50 & 100 & & ANOVA & Linear & Quadratic \\
\hline GSH-Px $(\mu \mathrm{mol} / \mathrm{L})$ & $234.54^{\mathrm{b}}$ & $240.01^{\mathrm{b}}$ & $295.48^{\mathrm{a}}$ & $272.37^{\mathrm{ab}}$ & 13.075 & 0.011 & 0.009 & 0.287 \\
\hline $\mathrm{SOD}(\mathrm{U} / \mathrm{mL})$ & $184.38^{\mathrm{b}}$ & $192.63^{\mathrm{a}}$ & $197.58^{\mathrm{a}}$ & $195.71^{\mathrm{a}}$ & 2.458 & 0.005 & 0.002 & 0.052 \\
\hline MDA (nmol/L) & $7.24^{\mathrm{a}}$ & $6.29^{\mathrm{b}}$ & $5.75^{\mathrm{b}}$ & $5.48^{\mathrm{b}}$ & 0.307 & 0.003 & $<0.001$ & 0.282 \\
\hline $\mathrm{LDH}(\mathrm{U} / \mathrm{mL})$ & 2076.0 & 1927.3 & 1841.3 & 1980.7 & 130.33 & 0.642 & 0.342 & 0.494 \\
\hline CPK (U/mL) & 2161.5 & 2389.7 & 2176.7 & 2189.2 & 175.87 & 0.772 & 0.870 & 0.546 \\
\hline $\mathrm{AP}(\mathrm{U} / \mathrm{mL})$ & 372.83 & 384.17 & 456.0 & 522.5 & 57.53 & 0.254 & 0.056 & 0.636 \\
\hline ALT (U/mL) & 13.33 & 13.16 & 12.16 & 10.66 & 1.385 & 0.518 & 0.161 & 0.635 \\
\hline
\end{tabular}

GABA, $\gamma$-aminobutyric acid; SEM, standard error of the mean; ANOVA, analysis of variance; GSH-Px, glutathione peroxidase; SOD, superoxide dismutase; MDA, malondialdehyde; LDH, lactate dehydrogenase; CPK, creatine phosphokinase; AP, alkaline phosphatase; ALT, alanine aminotransferase.

${ }^{\mathrm{a}, \mathrm{b}}$ Within a row, means that do not have a common superscript letter differ significantly. 
only involved in the synthesis of eggshells, but also play an important role in modulating the serum electrolyte balance (Hodges, 1969; Viveros et al., 2002). It was observed that freeze-dried GABA-producer improved concentration of serum calcium, phosphorus, potassium and sodium and this result might be related to transportation and absorption by GABA. Chen et al. (2013) noted that GABA could increase the activity of $\mathrm{Ca}^{2+}-\mathrm{Mg}^{2+}$-adenosine and $\mathrm{Na}^{+}-\mathrm{K}^{+}$-adenosine, benefiting the transportation of mineral elements. The ALP is present in different tissues of the body, and its activity reflects the absorption function of intestine (Sanderson and He, 1994). Increasing ALP activity and higher concentrations of calcium, phosphorus, potassium and sodium in GABA diets suggested that GABA-producer benefits transportation and absorption of mineral element, especially calcium and phosphorus.

A lack of disaccharidases can result in the inhibition of complete decomposition of carbohydrates, as well as in the absorption of monosaccharides conversion and utilization (Karamouz et al., 2011). In this context, Chen et al. (2013) found that while heat-stress inhibits the activity of sucrase and maltase in the intestinal mucosa of chickens, GABA alleviates this inhibition and this might explain the linear increase in serum glucose by freeze-dried GABA-producer in the present study. In addition, serum levels of protein and ALB were increased presumably of due to the GABAproducer functioning as the protein source. A decreased cholesterol level in hens was observed, and this result was consistent with the previous reports by Liong and Shah (2005) and Nguyen et al. (2007) that demonstrated a reduction in host cholesterol levels by LAB (Ooi and Liong, 2010).

Freeman and Crapo (1982) noted that heat-stress could stimulate the release of corticosterone and catecholamines and initiate lipid peroxidation in cell membranes, including membranes of $\mathrm{T}$ and $\mathrm{B}$ lymphocytes, leading to overproduction of oxygen free radicals $\mathrm{OH}$ and $\mathrm{O}_{2}$ (Slater, 1984). GSH-Px and SOD, as important components of the radical scavenging system, are involved in the process of antioxidation (Attia et al., 2006; Wei et al., 2011). They specifically catalyze reduction of glutathione (GSH) to clear $\mathrm{H}_{2} \mathrm{O}_{2}$ and reduce the generation of lipid peroxides, thus protecting the structure and functions of cell membrane. Huang et al. (2011) demonstrated that GABA might improve GSH-Px and SOD activities in pigeons. The possible explanation for above result is that the increase in glutamate level (an important ram material for the synthesis of GSH) was a result of an increased GABA content increasing the activity of the antioxidation enzyme. In this study, it was observed that increase in the level of GSH-Px and SOD was consistent with the observation of Chen et al. (2013), who reported that GABA could enhance the activities of GSH-Px and SOD in heat-stressed chickens.
Therefore, the present experimental results suggested that a GABA-producer could improve activity of GSH-Px and SOD as well as GABA.

Malondialdehyde is a product of peroxidation of unsaturated fatty acids in phospholipids and is responsible for cell membrane damage. In the present study, decreased MDA was obtained with increasing dietary GABA-producer, which might be attributed to the increased anti-oxidation GSH-Px and SOD activity. Similar results were reported by Baydas et al. (2005), Williams et al. (2006) and Attia et al. (2009), who observed that the decreased level of MDA was always accompanied by high activity of antioxidation enzymes.

The activity of ALP reflects the absorption function of the intestine (Sanderson and He, 1994), especially absorption of $\mathrm{Ca}$ and $\mathrm{P}$. In the present study, the activity of ALP tended to increase, suggesting that dietary GABAproducer could improve absorption of mineral elements, which can explain the increase in serum $\mathrm{Ca}, \mathrm{P}, \mathrm{K}$, and $\mathrm{Na}$, and thus increased eggshell quality.

The enzyme LDH is of medical significance as it is found almost in all body tissues (such as blood cells and heart muscle). It also acts as a marker for common injuries and diseases, because LDH is released during tissue damage. Creatine kinase, also known as CPK or phospho-creatine kinase, is an enzyme expressed by various tissues and cell types. Creatine kinase catalyzes the conversion of creatine and consumes adenosine triphosphate (ATP) to create phosphocreatine and adenosine diphosphate, therefore ATP can be generated from phosphocreatine and ADP. Generally, low levels of ALT are normally found in the blood. However, when the liver is damaged or diseased, it releases ALT into the bloodstream, which increases the ALT level in blood. In the present study, LDH, CPK, and ALT numerically decreased with increasing dietary GABAproducer, suggesting that GABA-producer could alleviate injuries of heat-stress to some extent. Nutritional regulation of GABA might be the reason for the above observation. Chan and Suk (2004) noted that GABA indirectly converted into glutamine in the intestine and glutamine was the major energy source of epithelial cells and lymphocytes and the nitrogen source for cell proliferation and differentiation. However, we did not obtained any significant benefit in hens from dietary freeze-dried GABA-producer due to the relative content of GABA in GABA-producer.

In conclusion, the present study demonstrated that the supplementation of dietary freeze-dried GABA-producer to heat-stressed Hy-Line brown hens could increase activity of antioxidation enzymes, modulate the electrolyte balance and improve feed intake of hens. Therefore, the improved immune function, antioxidation enzyme, electrolyte balance and feed intake ultimately resulted in the improvement of laying performance and egg quality. The present 
experimental result indicated that GABA-producer plays an important role in alleviating heat-stress. Thus, the isolated GABA-producer, which has a high ability to produce GABA, could be used as a natural and safe probiotic for improving laying performance and egg quality in heatstressed hens.

\section{ACKNOWLEDGMENTS}

This work was supported by Innovation fund for technology based firms (14C26213201211).

\section{REFERENCES}

Al-Harthi, M. A. 2014. The effect of natural and synthetic antioxidants on performance, egg quality and blood constituents of laying hens grown under high ambient temperature. Italian J. Anim. Sci. 13:444-449.

Attia, Y. A., R. A. Hassan, and E. M. A. Qota. 2009. Recovery from adverse effects of heat stress on slow-growing chicks in the tropics 1: Effect of ascorbic acid and different levels of betaine. Trop. Anim. Health Prod. 41:807-818.

Attia, Y. A., B. M. Böhmer, and D. A. Roth-Maier. 2006. Responses of broiler chicks raised under constant relatively high ambient temperature to enzymes, amino acid supplementations, or a high-nutrient diet. Archiv. Geflügelk. 70:80-91

Attia, Y. A, R. A. Hassan, A. E. Tag El-Din, and B. M. AbouShehema. 2011. Effect of ascorbic acid or increasing metabolizable energy level with or without supplementation of some essential amino acids on productive and physiological traits of slow-growing chicks exposed to chronic heat stress. J Anim. Physiol. Anim. Nutr. 95:744-755.

Belay, T. and R. G. Teeter. 1993. Broiler water balance and thermobalance during thermoneutral and high ambient temperature exposure. Poult. Sci. 72:116-124.

Baydas, G., E. Sonkaya, M. Tuzcu, A. Yasar, and E. Donder. 2005. Novel role for gabapentin in neuroprotection of central nervous system in streptozotocine-induced diabetic rats. Acta Pharmacol. Sin. 26:417-422.

Bloemhof, S., A. Kause, E. F. Knol, J. A. M. Van Arendonk, and I. Misztal. 2012. Heat stress effects on farrowing rate in sows: Genetic parameter estimation using within-line and crossbred models. J. Anim. Sci. 90:2109-2119.

Chan, H. O. and H. O. Suk. 2004. Effects of germinated brown rice extracts with enhanced levels of GABA on cancer cell proliferation and apoptosis. J. Med. Food 7:19-23.

Chen, Z., J. Tang, Y. Q. Sun, and J. Xie. 2013. Protective effect of $\gamma$-aminobutyric acid on antioxidation function in intestinal mucosa of Wenchang chicken induced by heat stress. J. Anim. Plant Sci. 23:1634-1641.

Cho, Y. R., J. Y. Chang, and H. C. Chang. 2007. Production of $\gamma-$ aminobutyric acid (GABA) by Lactobacillus buchneri isolated from kimchi and its neuroprotective effect on neuronal cells. J. Microbiol. Biotechnol. 17:104-109.

Dai, S. F., F. Gao, W. H. Zhang, S. X. Song, X. L. Xu, and G. H. Zhou. 2011. Effects of dietary glutamine and gamma- aminobutyric acid on performance, carcass characteristics and serum parameters in broilers under circular heat stress. Anim. Feed Sci. Technol. 168:51-60.

Feng, Y., X. J. Yang, Y. B. Wang, W. L. Li, Y. Liu, R. Q. Yin, and J. H. Yao. 2012. Effects of immune stress on performance parameters, intestinal enzyme activity and mRNA expression of intestinal transporters in broiler chicken. Asian Australas. J. Anim. Sci. 25:701-707.

Fox, D. G. and T. P. Tylutki. 1998. Accounting for the effects of environment on the nutrient requirements of dairy cattle. J. Dairy Sci. 81:3085-3095.

Freeman, B. A. and J. D. Crapo. 1982. Biology of disease: Free radicals and tissue injury. Lab. Invest. 47:412-426.

Hodges, R. D. 1969. pH and mineral ion levels in the blood of the laying hen (Gallus domesticus) in relation to egg shell formation. Comp. Biochem. Physiol. 28:1243-1257.

Huang, H. L., W. J. Zhao, X. T. Zou, H. Li, M. Zhang, and X. Y. Dong. 2011. Effect of $\gamma$-aminobutyric acid on incubation, immunity and antioxidant activity in pigeon. Chin J. Vet. Sci. 9:1327-1331.

Kim, S. H., B. H. Shin, Y. H. Kim, S. W. Nam, and S. J. Jeon. 2007. Cloning and expression of a full-length glutamate decarboxylase gene from Lactobacillus brevis $\mathrm{BH} 2$. Biotechnol. Bioprocess Eng. 12:707-712.

Kirunda, D. F. K., S. E. Scheideler, and S. R. Mckee. 2001. The efficacy of vitamin E (DL- $\alpha$-tocopheryl acetate) supplementation in hen diets to alleviate egg quality deterioration associated with high temperature exposure. Poult. Sci. 80:1378-1383.

Komatsuzaki, N., J. Shima, S. Kawamoto, H. Monose, and T. Kimura. 2005. Production of $\gamma$-aminobutyric acid (GABA) by Lactobacillus paracasei isolated from traditional fermented foods. Food Microbiol. 22:497-504.

Karamouz, H., J. G. Ghalehkandi, H. Z. A. Nazhad, Y. E. Nezhad, and N. M. Sis. 2011. Effect of different levels of zinc oxide supplement on mucosal sucrase enzyme activity in small intestine of male broiler chicks. Int. J. Anim. Vet. Adv. 3:54-57.

Larbier, Z. M., A. M. Chagneau, and P. A. Geraert. 1993. Influence of ambient temperature on true digestibility of protein and amino acids of rapeseed and soybean meals in broilers. Poult. Sci. 72:289-295.

Li, H., D. Gao, Y. Cao, and H. Xu. 2008. A high $\gamma$-aminobutyric acid-producing Lactobacillus brevis isolated from Chinese traditional paocai. Ann. Microbiol. 58:649-653.

Li, H. X., T. Qiu, G. D. Huang, and Y. S. Cao. 2010. Production of gamma-aminobutyric acid by Lactobacillus brevis NCL912 using fed-batch fermentation. Microb. Cell Fact. 9:85.

Liong, M.T. and N. P. Shah. 2005. Bile salt deconjugation ability, bile salt hydrolase activity and cholesterol co-precipitation ability of lactobacilli strains. Int. Dairy J. 15:391-398.

Mashaly, M. M., G. L. Hendricks 3rd, M. A. Kalama, A. E. Gehad, A. O. Abbas, and P. H. Patterson. 2004. Effect of heat stress on production parameters and immune responses of commercial laying hens. Poult. Sci. 83:889-894.

Miyazawa, T., T. Kawabata, K. Okazaki, T. Suzuki, D. Imai, T. Hamamoto, S. Matsumura, and T. Miyagawa. 2012. Oral administration of $\gamma$-aminobutyric acid affects heat production in a hot environment in resting humans. J. Physiol. Anthropol. $31: 3$. 
Nguyen, T. D. T., J. H. Kang, and M. S. Lee. 2007. Characterization of Lactobacillus plantarum $\mathrm{PH} 04$, a potential probiotic bacterium with cholesterol-lowering effects. Int. J. Food Microbiol. 113:358-361.

Nesamvuni, E., R. Lekalakala, D. Norris, and J. W. Ngambi. 2012. Effects of climate change on dairy cattle, South Africa. Afr. J. Agric. Res. 7:3867-3872.

National Research Council. 1994. Nutrient Requirements of Poultry, 9th rev. edn. National Academy Press, Washington, DC, USA.

Ole Miaron, J. O. and R. J. Christopherson. 1992. Effect of prolonged thermal exposure on heat production, reticular motility, rumen-fluid and -particulate passage-rate constants, and apparent digestibility in steers. Can. J. Anim. Sci. 72:809819.

Ooi, L. and M. Liong. 2010. Cholesterol-lowering effects of probiotics and prebiotics: A review of in vivo and in vitro findings. Int. J. Mol. Sci. 11:2499-2522.

Puthpongsiriporn, U., S. E. Scheideler, J. L. Sell, and M. M. Beck. 2001. Effects of vitamin $\mathrm{E}$ and $\mathrm{C}$ supplementation on performance, in vitro lymphocyte proliferation, and antioxidant status of laying hens during heat stress. Poult. Sci. 80:11901200.

Quinteiro-Filho, W. M., M. V. Rodrigues, A. Ribeiro, V. FerrazdePaula, M. L. Pinheiro, L. R. M. Sa, A. J. P. Ferreira, and J. Palermo-Neto. 2012. Acute heat stress impairs performance parameters and induces mild intestinal enteritis in broiler chicken: Role of acute hypothalamic-pituitary-adrenal axis activation. J. Anim. Sci. 90:1986-1994.

Rhoads, M. L., R. P. Rhoads, M. J. VanBaale, R. J. Collier, S. R. Sanders, W. J. Weber, B. A. Crooker, and L. H. Baumgard. 2009. Effects of heat stress and plane of nutrition on lactating Holstein cows: I. Production, metabolism, and aspects of circulating somatotropin. J. Dairy Sci. 92:1986-1997.
Sanderson, I. R. and Y. P. He. 1994. Nucleotide uptake and metabolism by intestinal epithelial cells. J. Nutr. 124:131S$137 \mathrm{~S}$.

SAS. 2004. SAS/STAT User's Guide Statistics, Version 9.1. SAS Inst., Inc., Cary, NC, USA.

Slater, T. F. 1984. Free-radical mechanisms in tissue injury. Biochem. J. 222:1-15.

Sliwowska, J. H., H. J. Billings, R. L. Goodman, and M. N. Lehman. 2006. Immunocytochemical colocalization of GABA-B receptor subunits in gonadotropin-releasing hormone neurons of the sheep. Neuroscience 141:311-319.

Tajalli, S., H. Jonaidi, M. Abbasnejad, and D. M. Denbow. 2006. Interaction between nociceptin/orphanin FQ (N/OFQ) and GABA in response to feeding. Physiol. Behav. 89:410-413.

Viveros, A., A. Brenes, I. Arija, and C. Centeno. 2002. Effects of microbial phytase supplementation on mineral utilization and serum enzyme activities in broiler chicks fed different levels of phosphorus. Poult. Sci. 81:1172-1183.

Watanabe, M., K. Maemura, K. Kanbara, T. Tamayama, and H. Hayasaki,, 2002. GABA and GABA receptors in the central nervous system and other organs. Int. Rev. Cytol. 213:1-47.

Wei, X. J., J. Wu, Y. D. Ni, L. Z. Lu, and R. Q. Zhao. 2011. Antioxidant effect of a phytoestrogen equol on cultured muscle cells of embryonic broilers. In Vitro Cell. Dev. Biol. 47:735741 .

Williams, A. J., C. C. Bautista, R. W. Chen, J. R. Dave, X. Lu, F. C. Tortella, and J. A. Hartings. 2006. Evaluation of gabapentin and ethosuximide for treatment of acute nonconvulsive seizures following ischemic brain injury in rats. J. Pharmacol. Exp. Ther. 318:947-955

Zhang, M., X. T. Zou, H. Li, X. Y. Dong, and W. J. Zhao. 2012. Effect of dietary gamma-aminobutyric acid on laying performance, egg quality, immune activity and endocrine hormone in heat-stressed Roman hens. Anim. Sci. J. 83:141147. 